\title{
Multiple sclerosis (MS) in the neighbouring islands of Sardinia, Italy, and Corsica, France
}

\author{
Klaus Lauer* \\ Eulerweg 4, D-64347, Griesheim, Germany
}

The world-wide prevalence of multiple sclerosis (MS) has been repeatedly reviewed [1,2], and the epidemiology of MS on the neighbouring islands of Sardinia and Corsica which are situated both in the middle of the Mediterranean Sea, has been studied extensively [3-6]. The MS prevalence in Sardinia was 149.7 per 100,000 population in the north-west (1997) [3], 143.9 in the central region (1993) [4], and 210.4 in the south-west (2007) [5]. In contrast, the MS prevalence was only 81.1 per 100,000 in Corsica (2003), which is northernly situated of Sardinia and now includes two départements of France [6]. The variation in crude MS prevalence of both regions is highly significant (four-fold table tests: $\mathrm{chi}^{2}=45.20$ for northern Sardinia); $\mathrm{chi}^{2}=32.63$ for central Sardinia; and $\mathrm{chi}^{2}=94.04$ for south-western Sardinia; all vs. Corsica, $\mathrm{p}<0.0001)$.

The question arises as to what extent genetic factors and the human environment contribute to that variation. However, a comparison of e.g. HLA subtypes of both populations is, at present, not possible. According to my knowledge, some extensive studies on genetic factors were made in Sardinia [7-9], but no investigation has been conducted in Corsica. It might be assumed, however, that genetic variations are minor since both populations are of Italian origin.

The meteorological conditions can be characterized as typical Mediterranean in both islands [10,11]. In Cagliari, Sardinia mean annual temperature was $16.6^{\circ} \mathrm{C}$ and the mean annual precipitation in 1901-1930 was $453.4 \mathrm{~mm}$. Subdivided by months, there were $9.4^{\circ} \mathrm{C}$ and $49.2 \mathrm{~mm}$ in January, and $24.5^{\circ} \mathrm{C}$ and $3.8 \mathrm{~mm}$ in July, respectively. In Bastia, northern Corsica (1931-1960), mean annual temperature was $14.9^{\circ} \mathrm{C}$ and the mean annual precipitation $735.0 \mathrm{~mm}$. In January, mean temperature and precipitation were $7.9^{\circ} \mathrm{C}$ and $75.0 \mathrm{~mm}$, and in July they were $23.0^{\circ} \mathrm{C}$ and $10.0 \mathrm{~mm}$, respectively. In Ajaccio, western Corsica, mean annual temperature and precipitation were $14.7^{\circ} \mathrm{C}$ and $672.0 \mathrm{~mm}$, in January $7.7^{\circ} \mathrm{C}$ and $76.0 \mathrm{~mm}$ and in July $22.0^{\circ} \mathrm{C}$ and 10.0 $\mathrm{mm}$, respectively. In summary, the data reflect only some difference in climate between the islands that are comparatively minor in extent.

With respect to meat smoking (vide infra), the plant distribution of both islands might be of interest. Sardinia has a rather common distribution of e.g. the genus Juniperus (J. oxycedrus; J. turbinata) [12] which is used locally for meat smoking, as in many parts of Europe. However, this species is also very common in Corsica [13]. Likewise the myrtle, a broad-leafy species which is also used for meat smoking in Sardinia [14], occurs commonly in Corsica [13]. Consequenly nearly no variation is present in the distribution of these plants that might explain the difference in MS prevalence.

The history of Sardinia [15] was characterized, after a long period of the prehistoric nuraghe culture (1500-400 BC), by the frequent invasion of foreign occupants (Phoenicians; Greeks; Carthaginians; Romans; Vandals; Byzantines; Saracens) until the first millenium. From the $11^{\text {th }}$ century, Sardinia was dominated by Pisa and Genoa which struggled permanently for predominance. In 1326 the Spanish house of Aragon gained control of the whole island. Aragon's predominance lasted until 1708, when Sardinia passed over to Austria. However, after only 10 years, the island was ceded to the house of Savoy and joined to the Piedmont region in upper Italy. Following the French revolution and the collapse of Napoleon's empire, Victor Emmanuel II who was king of Sardinia before, was proclaimed the souverain of the nation of Italy in 1861, which included now Sardinia as one of 21 regions [15]. Thus Sardinia had seen actually only a short period of northern European (i.e. Austrian) rule and influence which lasted only 10 years (17081718). This can hardly explain the long and, for a Mediterranean area, unusual type of meat preservation of the population.

In Corsica, following a megalithic period which lasted since the third millennium B.C., the recorded history [16] started in 560 B.C. when Greeks from Phocaea in Asia minor founded the city of Alalia on the east coast. In the following centuries Carthaginians, Romans, Vandals, Lombards, Arabs, Byzantines, and the municipalities of Pisa and Genoa, interrupted even by the "Corsican Republic" under the indigenous Pasquale Paoli (1755-1768), ruled the island until 1768. In that year, Genoa sold its rights on Corsica to France. Since that time, with short interruptions by the British in 1794-1796 and by Italian and German troops during WW2 in 1942-1943, Corsica remained a French region [16]. In summary, with exception of the mass migration in the first millennium A.C. when Germanic tribes appeared transiently on Corsica, no predominance of Northern Europeans was ever present. Thus, in final conclusion, northern European influence and possible subsequent changes in dietary habits, were much too short-lived to explain the difference in MS prevalence between both islands.

Among environmental factors, the discussions on the aetiology, at present, are dealing with infection by Epstein-Barr virus [17]; low vitamin D consumption [18]; cigarette smoking [18]; and the dietary intake of smoked and nitrite-cured meat and meat products $[19,20]$. Whereas no information was evident, at first, on the first three items in the Mediterranean region, some papers give an impression of the present diet [21-23]. It becomes evident that Sardinians have a long predilection for smoked meat and sausages [21], which appeared in contrast to the

${ }^{\star}$ Correspondence to: Klaus Lauer, MD, Assistant Professor, Eulerweg 4, D-64347, Griesheim, Germany, Tel: 4906155608899; E-mail: drklauslauer@aol.com

Received: August 09, 2018; Accepted: August 28, 2018; Published: August 31 , 2018 
many air-dried meat products preferred in continental Italy. One might speculate on possible reasons for this attitude. For example, the harsh, cold and humid climate in the interior large mountain areas of Sardinia [11] has always made difficult the drying of food, which fact might have left his dietary footprints until the present day.

In Corsica the picture on meat preservation is, at first, somewhat confusing. In one of the literary sources, meat smoking over the fucone (a large fire ignited before the churches at Christmas time) was extensively reported [22]. Another literary source [23], however, only rarely mentions smoking of meat in the chapter on sausage, lard and ham, and focusses almost exclusively on air-dried products (figatelli, salami, coppe, lonzi, vulette, panchette, prisutti, noci). Explicitly, it is mentioned (on lonzu) in that work that smoking should be made only during a short-time.Thus smoke might have been applied to repel invasion by vermin and insects, but this type of short-time smoking is insufficient for the long-term preservation of meat. In contrast, a true predilection for meat smoking seemed to be present in Sardinia over many centuries [21]. The reasons are, at first, unknown but differences in micro-climate of the islands might be one of the possibilities.

Thus, the hypothesis that the habit of meat smoking (especially the smoking of sausages at higher temperature) may play an important role in the aetiology of MS $[19,20]$ is supported by the epidemiologic distribution of MS in Sardinia and Corsica, respectively. This problem should be investigated more in detail by experts in history, epidemiology, human nutrition and food chemistry.

\section{References}

1. Rosati G (2001) The prevalence of multiple sclerosis in the world: an update. Neurol Sci 22: 117-139. [Crossref]

2. Pugliatti M, Rosati G (2008) Epidemiology of multiple sclerosis. In: Raine CS, McFarland HF, Hohlfeld R, eds. Multiple sclerosis: a comprehensive text. Edinburgh, UK: Saunders - Elsevier, pp: 121-140.

3. Pugliatti M, Sotgiu S, Solinas G, Castiglia P, Pirastru MI, et al. (2001) Multiple sclerosis epidemiology in Sardinia: evidence for a true increasing risk. Acta Neurol Scand 103: 20-26. [Crossref]

4. Casetta I, Granieri E, Marchi D, Murgia SB, Tola MR, et al. (1998) An epidemiological study of multiple sclerosis in central Sardinia, Italy. Acta Neurol Scand 98: 391-394. [Crossref]
5. Cocco E, Sardu C, Massa R, Mamusa E, Musu L, et al. (2011) Epidemiology of multiple sclerosis in south - western Sardinia. Mult Scler J 17: 1282-1289. [Crossref]

6. Fromont A, Binquet C, Sauleau EA, Fournel I, Bellisario A, et al. (2010) Geographic variations of multiple sclerosis in France. Brain 133: 1889-1899. [Crossref]

7. Piazza A, Olivetti E, Barbanti M, Reali G, Domenici R, et al. (1989) The distribution of some polymorphisms in Italy. Gene Geogr 3: 69-139. [Crossref]

8. La Mantia L, Illeni MT, Milanese C, Salmaggi A, Eoli M, et al. (1991) HLA antigens in Italian multiple sclerosis patients. Ital J Neurol Sci 12: 81-86. [Crossref]

9. La Mantia L, Illeni MT, Milanese C, Salmaggi A, Eoli M, et al. (1990) HLA and multiple sclerosis in Italy: a review of the literature. J Neurol 237: 441-444. [Crossref]

10. Arléry R (1970) The climate of France, Belgium, The Netherlands and Luxembourg. In: Landsberg HE, Wallén CC, eds.: Climates of Northern and Western Europe. Amsterdam, The Netherlands: Elsevier Publishing Company, pp: 135-193.

11. Cantù V (1977) The climate of Italy. In: Landsberg HE, Wallén CC, eds.: Climates of Central and Southern Europe. Amsterdam, The Netherlands: Elsevier Publishing Company, pp: 127-183.

12. Arrigoni PV (2006) Flora dell' isola di Sardegna (Vol. 1). Sassari, Italy: Carlo Delfino Editore.

13. Jeanmonod D, Gamisans J (2007). Flora Corsica. Aix-en-Provence, France: Édisud.

14. Anonymus (2018) What to eat in Sardinia? In: www.foodyoushouldtry.com. Access: August 19, 2018.

15. Safra JE, Aguilar-Cauz J (2010) The New Encyclopaedia Britannica, Micropaedia, 15th Edition, Vol. 3. Sardinia. Chicago IL, USA, pp: 451.

16. Safra JE, Aguilar-Cauz J (2010) The New Encyclopaedia Britannica, Micropaedia, 15th Edition, Vol.10. Corsica. Chicago IL, USA, pp: 651-652.

17. Ascherio A, Munger KL (2007) Environmental risk factors for multiple sclerosis. Part I: the role of infection. Ann Neurol 61: 288-299. [Crossref]

18. Ascherio A, Munger K (2008) Epidemiology of multiple sclerosis: from risk factors to prevention. Semin Neurol 28: 17-28. [Crossref]

19. Lauer K (2014) Notes on the epidemiology of multiple sclerosis, with special reference to dietary habits. Int J Mol Sci 15: 3533-3545. [Crossref]

20. Lauer K (2011) Dietary exposures and multiple sclerosis: a review. Rev Esp Escl Múlt 3: $13-21$.

21. Vittorini E, Turri E (1964) Sardinien. Lausanne, Switzerland: Editions Rencontre.

22. Schapira C (1979) La cuisine corse. Paris, France: Solar Éditeurs.

23. Stromboni N (2017) Das Kochbuch - autentisch, einfach, echt. Munich, Germany: Christian Verlag. Original (2016): Du pain, du vin, des oursins. Vanves, France: Hachette Livre Marabout.

Copyright: (C2018 Lauer K. This is an open-access article distributed under the terms of the Creative Commons Attribution License, which permits unrestricted use, distribution, and reproduction in any medium, provided the original author and source are credited. 